\title{
Mechanical Characterization of Ti-12Mo-13Nb Alloy for Biomedical Application Hot Swaged and Aged
}

\author{
Sinara Borborema Gabriel ${ }^{a, b *}$, Jean Dille ${ }^{c}$, Monica Castro Rezende ${ }^{a}$, Paulo Mei ${ }^{d}$, \\ Luiz Henrique de Almeida, Renato Baldan ${ }^{e}$, Carlos Angelo Nunes ${ }^{e}$ \\ ${ }^{a}$ Departamento de Engenharia Metalúrgica e de Materiais, Universidade Federal do Rio de Janeiro- \\ UFRJ, CP 68505, CEP 21945-970, Rio de Janeiro, RJ, Brazil \\ ${ }^{b}$ Centro Universitário de Volta Redonda - UniFOA, Avenida Paulo Erlei Alves Abrantes, 1325, \\ Três Poços, CEP 27240-560, Volta Redonda, RJ, Brazil \\ ‘4MAT Department, Université Libre de Bruxelles - ULB, Avenida F. Roosevelt, 50, \\ CP 194/03, Brussels, Belgium \\ ${ }^{d}$ Departamento de Engenharia Mecânica, Universidade Estadual de Campinas - UNICAMP \\ Rua Mendeleyev, 200, Cidade Universitária, CEP 13083-860, Campinas, SP, Brazil \\ ${ }^{e}$ Departamento de Engenharia de Materiais, Escola de Engenharia, Universidade de São Paulo - USP, \\ CP 116, CEP 12600-970, Lorena, SP, Brazil
}

Received: September 15, 2014; Revised: August 30, 2015

\begin{abstract}
Beta titanium alloys were developed for biomedical applications due to the combination of its mechanical properties including low elasticity modulus, high strength, fatigue resistance, good ductility and with excellent corrosion resistance. With this perspective a metastable beta titanium alloy $\mathrm{Ti}-12 \mathrm{Mo}-13 \mathrm{Nb}$ was developed with the replacement of both vanadium and aluminum from the traditional alloy Ti-6Al-4V. This paper presents the microstructure, mechanical properties of the Ti$12 \mathrm{Mo}-13 \mathrm{Nb}$ hot swaged and aged at $500{ }^{\circ} \mathrm{C}$ for $24 \mathrm{~h}$ under high vacuum and then water quenched. The alloy structure was characterized by X-ray diffraction and transmission electron microscopy. Tensile tests were carried out at room temperature. The results show a microstructure consisting of a fine dispersed $\alpha$ phase in a $\beta$ matrix and good mechanical properties including low elastic modulus. The results indicate that $\mathrm{Ti}-12 \mathrm{Mo}-13 \mathrm{Nb}$ alloy can be a promising alternative for biomedical application.
\end{abstract}

Keywords: Ti-Mo-Nb alloy, microstructure, mechanical properties

\section{Introduction}

The increase in life expectancy of the population has led to a greater number of older people ${ }^{1}$ and this in turn, has increased the demand for materials suitable to biomedical implants ${ }^{2}$. It is estimated that through 2030 will be performed only in the United States per year approximately 272,000 total hip replacements ${ }^{3}$.

Biomaterials used for replacement implants have to combine excellent biocompatibility with appropriate mechanical properties.

The biocompatibility of a metallic implant is directly determined by its corrosion resistance and the biological effects of released metallic ions. These effects are diverse: cytotoxicity (inducing cell or tissue death), genetic damage or immune response ${ }^{4}$. On the other hand, the most important mechanical requirements for metallic biomaterials are: low Young's modulus, high yield strength and ultimate tensile strength, good fatigue resistance and sufficient ductility ${ }^{5}$. A low value of Young's modulus is required in order to minimize the modulus mismatch between implant and surrounding bone tissues. Indeed, this stiffness mismatch can induce the stress shielding phenomenon. Stress shielding occurs

*e-mail: sinara@metalmat.ufrj.br where the metal carries a majority of applied load, leaving the more compliant tissue almost unstressed. This will lead to the undesirable effect termed bone disuse atrophy, a form of osteoporosis, around the implant site ${ }^{6}$.

Moreover, the metallic alloys used for implants are also required to have high yield strength in order to support the complex stresses applied to the implants during their lifetime.

In general, yield strength and Young's modulus vary in opposite way for metallic materials ${ }^{7,8}$. Lower Young's modulus corresponds to lower yield strength. Therefore, it is necessary to find the best compromise between these two mechanical properties. For this reason, yield strength to Young's modulus ratio is often used as key indicator in order to evaluate the mechanical performance of metallic biomaterials for implant applications ${ }^{9}$.

The more conventional metallic materials used as orthopedic implants are: stainless steel, Co-Cr alloys and commercially pure $\mathrm{Ti}(\mathrm{cp})$ and its alloys. In this last class, the most widely used is the Ti-6Al-4V alloy ${ }^{10}$. The literature indicates that long term health problems would be associated with the release of $\mathrm{Al}$ and $\mathrm{V}$ ions from the Ti-6Al-4V metallic implants into the human body. The presence of $\mathrm{V}$ ions into tissues can alter the kinetics of the enzyme activity associated with the 
inflammatory response cells ${ }^{11}$ whereas presence of Al ions increases the potential for the development of Alzeimer's disease ${ }^{12}$. Eisenbarth et al. ${ }^{13}$ mention, on the other hand, that vanadium is toxic both in elemental form and as oxides.

For these reasons, a number of studies have recently focused on the development of metastable $\beta$-type Ti alloys with non-toxic elements such as $\mathrm{Mo}, \mathrm{Zr}, \mathrm{Sn}$, Ta and $\mathrm{Nb}^{[14-23]}$ In addition to an excellent corrosion resistance in human body fluids, $\beta$-type titanium alloys exhibit lower Young's modulus than $\alpha$ and $\alpha+\beta$ alloys. Moreover, the control of thermomechanical processing parameters permits to obtain the microstructure conferring the optimum yield strength to Young's modulus ratio to the alloy. Typical mechanical properties of conventional metallic biomaterials and $\beta$-type Ti alloys are shown in Table $1^{24}$. In comparison with stainless steel and Co-Cr alloys, $\beta$-Ti alloys exhibit a much lower Young's modulus and a much higher yield strength to Young's modulus ratio.

Studies realized by Gabriel et al. ${ }^{25}$ on the processing of the Ti-12Mo-13Nb alloy with equivalent concentration of molybdenum (15.4) showed that the highest specific hardness modulus ratio was obtained in the condition aged at $500{ }^{\circ} \mathrm{C} / 24 \mathrm{~h}$ and this ratio is higher than for Ti-6Al-4V alloy. Therefore, Ti-12Mo-13 Nb alloy has a high potential to be applied as a bone substitute in places subjected to mechanical loading. Moreover, a recent in vitro research indicates that the Ti-Mo-Nb alloys show a very good biocompatibility ${ }^{26}$. However, additional studies are needed to optimize the mechanical behavior of the Ti-12Mo-13Nb alloy.

Thus, the aim of this project is to analyze the microstructure and the mechanical behavior of Ti-12Mo-13 Nb alloy hot forged and aged for biomedical applications aiming to replace Ti-6Al-4V alloy currently used.

\section{Material and Methods}

\subsection{Material preparation}

The Ti-12Mo-13Nb alloy was prepared from commercially pure $\mathrm{Ti}$ with the addition of $\mathrm{Mo}$ and $\mathrm{Nb}$ in an arc melting furnace with a tungsten electrode on a water-cooled copper hearth. The alloy was prepared in a high purity argon atmosphere and the ingot was re-melted five times to improve chemical homogeneity. The obtained ingot (40 g) was solution-treated at $1000^{\circ} \mathrm{C}$ under high vacuum for $24 \mathrm{~h}$ inside a tubular furnace, followed by quenching in water at room temperature. It was then swaged at $900-1000{ }^{\circ} \mathrm{C}$ with an $80 \%$ reduction in area. The sample (cylindrical in shape) was aged at $500{ }^{\circ} \mathrm{C}$ under high vacuum for $24 \mathrm{~h}$ in a tubular furnace, and then quenched in water at room temperature.

\subsection{Phase characterization}

Phase characterization was carried out using X-ray diffraction (XRD, Shimadzu model XRD 6000 diffractometer) operated at $40 \mathrm{kV}, 30 \mathrm{~mA}$ and $\mathrm{CuK}_{\alpha}$ radiation $(\lambda=1.5418 \AA)$. The phases were identified through comparison with simulated diffraction pattern using the program Powdercell ${ }^{27}$, inserting data of $\alpha, \omega$ and $\beta$-Ti phases as space groups, lattice parameters and atomic positions ${ }^{28}$.

The microstructure of the alloy was also investigated by transmission electron microscopy (TEM) using a Philips CM20 operated at $200 \mathrm{kV}$. The thin foils for this procedure were prepared using a twin-jet electropolishing machine in a solution containing $(60 \mathrm{~mL}) \mathrm{HClO}_{4},(590 \mathrm{~mL})$ methanol, and $(350 \mathrm{~mL})$ ether monobutylethylene at $35 \mathrm{~V}$ and $-20^{\circ} \mathrm{C}$.

\subsection{Measurement of young modulus and tensile tests}

The Young's modulus (YM) was determined by the instrumented indentation technique using a Nanoindenter. Three sets of nine indentations were made using a Berkovich tip, with an applied load of $400 \mathrm{mN}$ corresponding to one complete loading-unloading cycle and with a peak hold time of 15 seconds. The obtained modulus value was the average of 27 measurements. For comparison, the Young's modulus of Ti-6Al-4V was also determined under the same conditions.

Tensile tests were performed at room temperature on specimens with $22.7 \mathrm{~mm}$ in length and $4 \mathrm{~mm}$ in diameter and using a strain rate of $4 \times 10^{-3} \mathrm{~s}^{-1}$. Ti-12Mo-13Nb in the aged condition and reference Ti-6Al-4V specimens were tested to rupture. From the stress-strain curves, the yield strength (YS), the ultimate tensile strength (UTS) and the elongation at rupture (EL) can be determined.

\section{Results and Discussion}

\subsection{Microstructural characterization}

Figure 1 shows the XRD pattern of the Ti-12Mo-13Nb alloy aged at $500{ }^{\circ} \mathrm{C}$ for $24 \mathrm{~h}$ and quenched. Reflections from $\alpha$ and $\beta$ phases were identified in the sample. On the other hand, the presence of $\omega$ phase has not been detected. Precipitation of $\alpha$ phase or $\omega$ phase can occur into the $\beta$ matrix, depending on the aging parameters ${ }^{29}$. The XRD results show that after an aging of $24 \mathrm{~h}$ at $500{ }^{\circ} \mathrm{C}$, only $\alpha$ precipitates exist in the $\beta$ matrix of aged Ti-12Mo-13Nb alloy.

Table 1. Mechanical properties of typical biomaterials ${ }^{24}$.

\begin{tabular}{|c|c|c|c|c|}
\hline Alloy & $\begin{array}{c}\text { YM } \\
(\mathbf{G P a})\end{array}$ & $\begin{array}{c}\text { YS } \\
(\mathbf{M P a})\end{array}$ & $\begin{array}{l}\text { strength-to-modulus } \\
\text { ratio }\left(\times 10^{-3}\right)\end{array}$ & $\begin{array}{c}\text { EL } \\
\text { (\%) }\end{array}$ \\
\hline V 316(stainless steel) & 379 & 793 & 2.1 & 22 \\
\hline$(\mathrm{Co}-\mathrm{Cr}-\mathrm{Mo})$ & 220 & 448 & 2.0 & 8 \\
\hline $\mathrm{Ti}(\mathrm{cp})$ & $103-104$ & $170-485$ & $1.6-4.7$ & $15-24$ \\
\hline Ti-6Al-4V & 124 & 896 & 7.2 & $13-16$ \\
\hline Ti-50Ta (aged) & 77 & 612 & 7.9 & 11.6 \\
\hline Ti-13Nb-13Zr (aged) & $79-84$ & $836-908$ & $10-11.5$ & $6-10$ \\
\hline Ti-15Mo (annealed) & 78 & 544 & 7.0 & 21 \\
\hline
\end{tabular}


The bright-field micrograph of aged Ti-12Mo-13Nb alloy obtained by TEM is shown in Figure 2. After the aging treatment, fine $\alpha$ precipitates (in white) with platelet morphology were observed dispersed in the $\beta$ matrix. These precipitates are a few nanometers thick and a few hundreds of nanometers long.

\subsection{Mechanical characterization}

The values obtained for the measurements of Young's modulus using the nanoindentation technique were $140 \mathrm{GPa}$ for the reference $\mathrm{Ti}-6 \mathrm{Al}-4 \mathrm{~V}$ alloy and $110 \mathrm{GPa}$ for $\beta$-Ti-12Mo- $13 \mathrm{Nb}$ alloy. This indicates a $21 \%$ reduction in the Young's modulus of the alloy described in the present work.

The lower Young's modulus of the Ti-12Mo-13Nb alloy can mainly be attributed to the Mo and $\mathrm{Nb}$ atoms in solid solution. Niobium and molybdenum have high solubility in titanium but also larger atomic radius. The calculated atomic radius is $248 \mathrm{pm}$ for $\mathrm{Ti}$ whereas it is $320 \mathrm{pm}$ for $\mathrm{Nb}$ and $306 \mathrm{pm}$ for Mo. At the contrary, the atomic radii of Al and

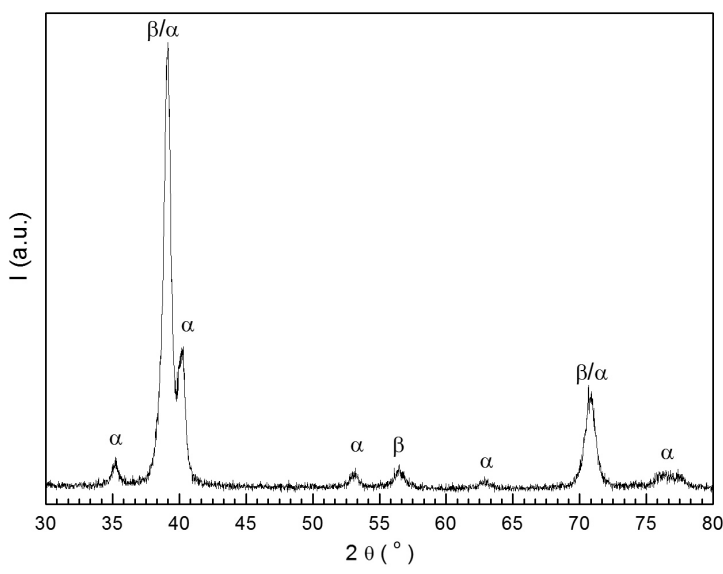

Figure 1. X-ray diffraction pattern of the Ti-12Mo-13Nb alloy hot swaged and aged at $500^{\circ} \mathrm{C} / 24 \mathrm{~h}$, showing diffraction peaks from $\alpha$ and $\beta$ phases.

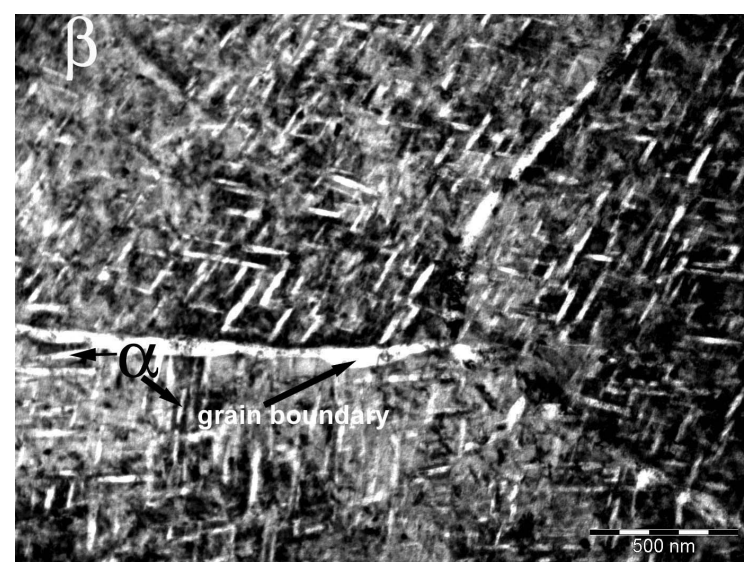

Figure 2. TEM image (bright-field) of Ti-12Mo-13Nb alloy hot swaged and aged at $500{ }^{\circ} \mathrm{C} / 24 \mathrm{~h}$ showing a fine distribution of $\alpha$ precipitates in the $\beta$ matrix.
$\mathrm{V}$ are smaller, respectively $118 \mathrm{pm}$ for $\mathrm{Al}$ and $171 \mathrm{pm}$ for $\mathrm{V}^{[30]}$. It has been shown that a decrease of Young's modulus is associated with the presence of substitutional atoms with larger atomic radius in the Ti lattice. This presence reduces the binding force of the lattice by expanding unit cell volume ${ }^{31}$.

Figure 3 shows the stress-strain curves at room temperature for the aged Ti-12Mo-13Nb alloy and the Ti-6Al-4V alloy.

The obtained yield strength, ultimate tensile strength and elongation are given in Table 2 along with Young's modulus and yield strength on Young's modulus ratio values for both tested alloys.

The strengthening effect of fine $\alpha$ precipitation during the $24 \mathrm{~h}$ aging heat treatment at $500{ }^{\circ} \mathrm{C}$ gives a higher strength to Ti-12Mo-13Nb alloy compared to Ti-6Al-4V alloy.

On the other hand, Young's modulus does not only depend on chemical composition but it depends also on the applied thermomechanical process.

For $\beta$-Ti alloys, aging treatments induce a strengthening of the material due to fine $\alpha$ or $\omega$ phase precipitation but this precipitation also leads to an increase of Young's modulus. This increase is much more important for $\omega$ phase precipitation than for $\alpha$ phase precipitation ${ }^{7,32}$. The structural characterization by XRD and transmission electron microscopy has shown that the aging heat treatment at $500{ }^{\circ} \mathrm{C}$ during $24 \mathrm{~h}$ avoids the precipitation of the most deleterious $\omega$ phase and permits so to obtain the highest yield strength to Young's modulus ratio with only the fine precipitation of $\alpha$ phase. However, this fine precipitation also induces a lower ductility for the aged Ti-12Nb-13Mo compared to Ti-6Al-4V alloy. Nevertheless, the elongation of $6 \%$ at rupture, revealed by the tensile test, indicates that the aged Ti-12Nb-13Mo does not show any brittle behavior. On the other hand, a high ductility is, in fact, only required for the forming operations. Therefore, the Ti-12Nb-13Mo alloy has to be hot or cold formed before the aging treatment when its structure consists of $100 \%$ of more ductile $\beta$ phase. In this work, the material was hot swaged at $900{ }^{\circ} \mathrm{C}-1000{ }^{\circ} \mathrm{C}$. This range of temperatures lies inside the stability area of $\beta$ phase.

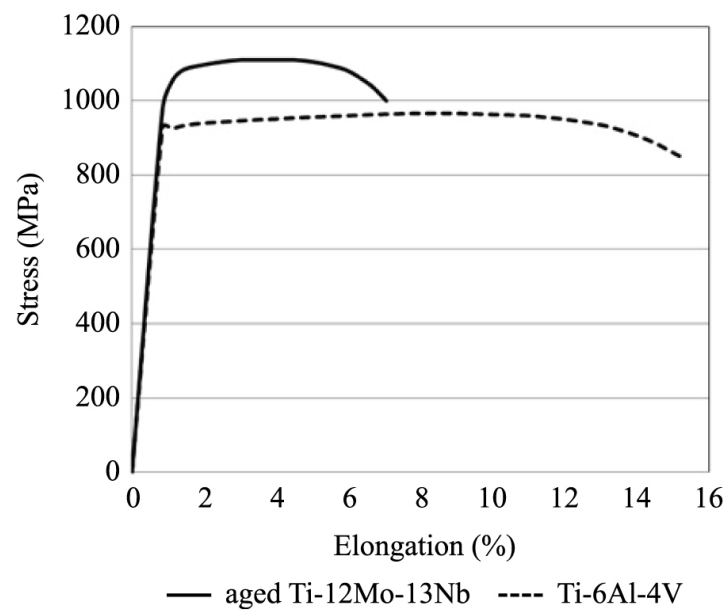

Figure 3. Stress-strain curves of aged Ti-12Mo-13Nb alloy and Ti-6Al4V alloy at room temperature and strain rate of $4 \times 10^{-3} \mathrm{~s}^{-1}$. 
Table 2. Mechanical properties of Ti-6Al-4V and aged Ti-12Nb-13Mo alloys.

\begin{tabular}{lccccc}
\hline \multicolumn{1}{c}{ Alloy } & $\begin{array}{c}\text { YM } \\
(\mathbf{G P a})\end{array}$ & $\begin{array}{c}\text { YS } \\
(\mathbf{M P a})\end{array}$ & $\begin{array}{c}\text { UTS } \\
(\mathbf{M P a})\end{array}$ & $\begin{array}{c}\text { strength- } \\
\text { to-modulus } \\
\text { ratio }\left(\times \mathbf{1 0}^{-3}\right)\end{array}$ & $\begin{array}{c}\text { EL } \\
(\mathbf{\%})\end{array}$ \\
\hline $\mathrm{Ti}-6 \mathrm{Al}-4 \mathrm{~V}$ & $140 \pm 3.36$ & 930 & 966 & 6.6 & 14.2 \\
Ti-12Nb-13Mo (aged) & $110 \pm 2.62$ & 981 & 1111 & 8.9 & 6.3 \\
\hline
\end{tabular}

\section{Conclusions}

The results show than the Ti-12Mo-13Nb alloy hot forged and aged at $500{ }^{\circ} \mathrm{C}$ for $24 \mathrm{~h}$ presented a microstructure consisting of very fine dispersed $\alpha$ phase in a $\beta$ matrix and consequently with good mechanical properties. The values obtained for the ratio of strength to Young's modulus of the present alloy are higher than those of the commercially available Ti-6Al-4V alloy. The results indicate that Ti-12Mo-13Nb

\section{References}

1. Gunawarman B, Niinomi M, Akahori T, Takeda J and Toda H. Mechanical properties of Ti-4,5Al-3V-2Mo-2Fe and possibility for healthcare applications. Materials Science and Engineering C. 2005; 25:96-303.

2. Oliveira NTC and Guastaldi AC. Electrochemical behavior of Ti-Mo alloys applied as biomaterial. Corrosion Science. 2008; 50(4):938-945. http://dx.doi.org/10.1016/j.corsci.2007.09.009.

3. Rack HJ and Qazi JI. Titanium alloys for biomedical applications. Materials Science and Engineering C. 2006; 26(8):1269-1277. http://dx.doi.org/10.1016/j.msec.2005.08.032.

4. Chen Q and Thouas GA. Metallic implant biomaterials. Materials Science and Engineering R Reports. 2015; 87:1-57. http://dx.doi.org/10.1016/j.mser.2014.10.001.

5. Geetha M, Singh AK, Asokamani R and Gogia C. Ti based biomaterials, the ultimate choice for orthopaedic implants - a review. Progress in Materials Science. 2009; 54(3):397-425. http://dx.doi.org/10.1016/j.pmatsci.2008.06.004.

6. Li Y, Yang C, Zhao H, Qu S, Li X and Li YY. New developments of Ti-based alloys for biomedical applications. Materials. 2014; 7(3):1709-1800. http://dx.doi.org/10.3390/ma7031709.

7. Niinomi M. Mechanical properties of biomedical titanium alloys. Materials Science and Engineering A. 1998; 243(1-2):231-236.

8. Bania PJ, Lenning GA and Ball JA. Beta titanium alloys. In: Boyer RR and Rosenberg HW, editors. Beta titanium alloys in the 1980s. Warrendale: AIME; 1984. p. 209-229.

9. Guo S, Meng Q, Liao G, Hu L and Zhao X. Progress in natural science. Materials International. 2013; 23:174-182.

10. Zhou YL, Niinomi M, Akahori T, Fukui H and Toda H. Corrosion resistance and biocompatibility of Ti-Ta alloys for biomedical applications. Materials Science and Engineering A. 2005; 398(1-2):28-36. http://dx.doi.org/10.1016/j.msea.2005.03.032.

11. Mohammed MT, Khan ZA, Geetha M and Siddiquee AN. Microstructure, mechanical properties and electrochemical behavior of a novel biomedical titanium alloy subjected to thermo-mechanical processing including aging. Journal of Alloys and Compounds. 2014; 634:272-280.

12. Xu LJ, Chen YY, Liu ZG and Kong FT. The microstructure and properties of $\mathrm{Ti}-\mathrm{Mo}-\mathrm{Nb}$ alloys for biomedical application. Journal of Alloys and Compounds. 2008; 453(1-2):320-324. http://dx.doi.org/10.1016/j.jallcom.2006.11.144. alloy is competitive compared to the other $\beta$-Ti alloys listed in Table 1 and can be a promising alternative for biomedical applications.

\section{Acknowledgements}

This work was supported by CNPq, FAPERJ, CAPES and UniFOA.

13. Eisenbarth E, Velten D, Müller M, Thull R and Breme J. Biocompatibility of beta-stabilizing elements of titanium alloys. Biomaterials. 2004; 25(26):5705-5713. http://dx.doi. org/10.1016/j.biomaterials.2004.01.021. PMid:15147816.

14. Guo S, Meng QK, Cheng XN and Zhao XQ. Deformation behavior of metastable $\beta$-type Ti-25Nb-2Mo-4Sn alloy for biomedical applications. Journal of the Mechanical Behavior of Biomedical Materials. 2014; 38:26-32. http://dx.doi. org/10.1016/j.jmbbm.2014.06.006. PMid:25011015.

15. Kuroda D, Niinomi M, Morinaga M, Kato Y and Yashiro T. Design and mechanical properties of new $\beta$ type titanium alloys for implant materials. Materials Science and Engineering $A$. 1998; 243(1-2):244-249. http://dx.doi.org/10.1016/S09215093(97)00808-3.

16. Gabriel SB, Nunes CA and Soares GA. Production, microstructural characterization and mechanical properties of as-cast Ti-10MoxNb alloys. Artificial Organs. 2008; 32(4):299-304. http://dx.doi. org/10.1111/j.1525-1594.2008.00546.x. PMid:18370944.

17. Gabriel SB, Dille J, Nunes CA and Soares GA. THe effect of niobium content on the hardness and elastic modulus of heattreated ti-10mo-xnb alloys. Materials Research. 2010; 13(3):1-5. http://dx.doi.org/10.1590/S1516-14392010000300009.

18. Cremasco A, Osório WH, Freire CMA, Garcia A and Caram R. Electrochemical corrosion behavior of a Ti-35Nb alloy for medical prostheses. Electrochimica Acta. 2008; 53(14):48674874. http://dx.doi.org/10.1016/j.electacta.2008.02.011.

19. Afonso CRM, Aleixo GT, Ramirez AJ and Caram R. Influence of cooling rate on microstructure of $\mathrm{Ti}-\mathrm{Nb}$ alloy for orthopedic implants. Materials Science and Engineering C. 2007; 27(4):908913. http://dx.doi.org/10.1016/j.msec.2006.11.001.

20. Gordin DM, Gloriant T, Nemtoi G, Chelariu R, Aelenei N, Guillou A, et al. WITHDRAWN: synthesis, structure and electrochemical behavior of a beta Ti-12Mo-5Ta alloy as new biomaterial. Materials Letters. 2005; 59(23):2959-2964. http:// dx.doi.org/10.1016/j.matlet.2004.09.064.

21. Banerjee R, Nag S and Fraser HL. A novel combinatorial approach to the development of beta titanium alloys for orthopaedic implants. Materials Science and Engineering C. 2005; 25(3):282289. http://dx.doi.org/10.1016/j.msec.2004.12.010.

22. Xu W, Kim KB, Das J, Calin M and Eckert J. Phase stability and its effect on the deformation behavior of Ti-Nb-Ta- $\mathrm{In} / \mathrm{Cr}$ $\beta$ alloys. Scripta Materialia. 2006; 54(11):1943-1948. http:// dx.doi.org/10.1016/j.scriptamat.2006.02.002. 
23. Oliveira NTC, Aleixo G, Caram R and Guastaldi AC. Development of Ti-Mo alloys for biomedical applications: Microstructure and electrochemical characterization. Materials Science and Engineering A. 2005; 452-453:727-731. http:// dx.doi.org/10.1016/j.msea.2006.11.061.

24. Zhou $Y$ and Niinomi M. Microstructures and mechanical properties of Ti-50mass \% Ta alloy for biomedical applications. Journal of Alloys and Compounds. 2008; 466(1-2):535-542. http://dx.doi.org/10.1016/j.jallcom.2007.11.090.

25. Gabriel SB, Almeida LH, Nunes CA, Dille J and Soares GA. Maximisation of the ratio of microhardness to the Young's modulus of Ti-12Mo-13Nb alloy through microstructure changes. Materials Science and Engineering C. 2013; 33(6):3319-3324. http://dx.doi.org/10.1016/j.msec.2013.04.015. PMid:23706216.

26. Neacsu P, Gordin D-M, Mitran V, Gloriant T, Costache M and Cimpean V. In vitro performance assessment of new beta Ti-Mo$\mathrm{Nb}$ alloy compositions. Materials Science and Engineering $C$. 2015; 47:105-113. http://dx.doi.org/10.1016/j.msec.2014.11.023. PMid:25492178.

27. Kraus W and Nolze GJ. POWDER CELL: a program for the representation and manipulation of crystal structures and calculation of the resulting X-ray powder patterns. Journal of Applied Crystallography. 1996; 29(3):301-303. http://dx.doi. org/10.1107/S0021889895014920.

28. Villars P and Calvert LD. Pearson's handbook of crystallographic data for intermetallic phases. 2nd ed. Ohio: Metals Park; 1991

29. Hao YL, Niimoni M, Kuroda D, Fukunaga K, Zhou YL, Yang R, et al. Young modulus and mechanical properties of Ti-29Nb-13 Ta-4.6Zr in relation to $\alpha$ " martensite". Metallugical and Materials Transactions A. 2002; 33:3137-3144.

30. Ghosh DC and Biswas L. Theoretical calculation of absolute radii of atoms and Ions. Part 1 . The atomic radii. International Journal of Molecular Sciences. 2002; 3(2):87-113. http://dx.doi. org/10.3390/i3020087.

31. Liu Q, Meng Q, Guo S and Zhao X. Progress in materials science. Materials. 2013; 23:562-565.

32. Jung T-K, Semboshi S, Masahashi N and Hanada S. Mechanical properties and microstructures of $\beta \mathrm{Ti}-25 \mathrm{Nb}-11 \mathrm{Sn}$ ternary alloy for biomedical applications. Materials Science and Engineering C. 2013; 33(3):1629-1635. http://dx.doi.org/10.1016/j. msec.2012.12.072. PMid:23827617. 